Hydrol. Earth Sys. Sci. Discuss., 2, 731-760, 2005

www.copernicus.org/EGU/hess/hessd/2/731/

\title{
Phreatic surface fluctuations within the tropical floodplain paddy field of the Yom River, Thailand
}

S. Chuenchooklin ${ }^{1}$, T. Ichikawa ${ }^{2}$, S. Patamatamkul ${ }^{3}$, V. Sriboonlue ${ }^{3}$, and C. Kerdpitaksa ${ }^{4}$

${ }^{1}$ Graduate School Khon Kaen University, Khon Kaen, 40002, Thailand

${ }^{2}$ School of Engineering, Kyushu Tokai University, Toroku, Kumamoto, Japan

${ }^{3}$ Faculty of Engineering, Khon Kaen University, Khon Kaen, 40002, Thailand

${ }^{4}$ Faculty of Engineering, Kasetsart University, Bangkok, 10900, Thailand

Received: 11 March 2005 - Accepted: 20 April 2005 - Published: 19 May 2005

Phreatic surface

fluctuations within

the tropical

floodplain

S. Chuenchooklin et al.

Correspondence to: S. Chuenchooklin (sombatck@ hotmail.com)

(C) 2005 Author(s). This work is licensed under a Creative Commons License.

Print Version

Interactive Discussion 


\section{Abstract}

The fluctuation of phreatic surfaces in tropical floodplain was studied for the lower part of the Yom's river basin at Phichit Province in Thailand. The simple water balance budget model was applied to estimate the groundwater recharge. The hydrologic com5 ponents i.e. average rainfall, surface runoff, and deep percolation were calculated by using climatologically recorded and measured data. The Penman-Monteith's evapotranspiration method was used to estimate potential evapotranspiration for crop water requirement based on climatic data. The 49-points of field infiltration and theirs distribution over the floodplain were measured using ring-infiltrometers. The surface water 10 and phreatic surface deviations from the existing 22-observation wells nearby the Yom River daily observed continuously for 3 years. The observed river water levels and phreatic surface water levels were agreed very well with $R^{2}$ approx. 0.90 . The rising or recessing of those fluctuations was depended on the inundated depth over floodplain or the amount of groundwater withdrawal for crop consuming. Understanding and 15 quantifying the phreatic surface fluctuations in lowland paddy field is crucial for further floodplain management.

\section{Introduction}

In a large floodplain area of a large river in tropical-monsoon zone with high intense rainfall during rainy season, its hydrological parameters and components are difficult to determine due to complex physical conditions. Usually, flood occurs when there is too much water over specific area by rainwater, additional flow entering from adjacent upstream area, and overbank flow from the river itself. The period of inundation will be based on floodplain morphology, and hydrogeological characteristics. Moreover, the great amount of withdrawal of both surface and subsurface waters for crop consuming especially paddy in floodplain will affect the change of phreatic surfaces. Those physical behaviors over the specific floodplain catchments should be better investigated

\section{HESSD}

2, 731-760, 2005

Phreatic surface

fluctuations within

the tropical

floodplain

S. Chuenchooklin et al.

\section{Title Page}

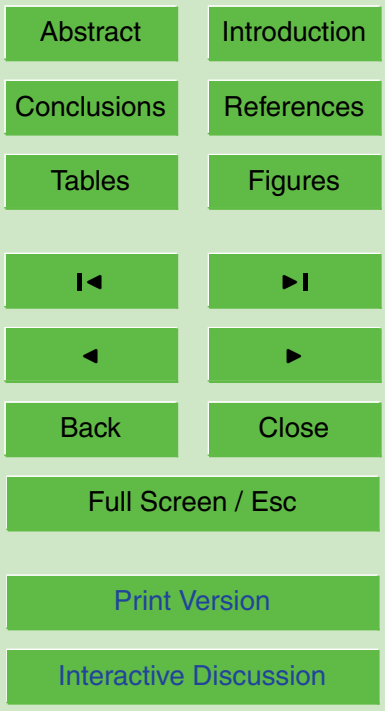

EGU 
from the field. The infiltration which is one of the major hydrologic components of water penetrating from the ground surface into the soil that might percolates contribute, further and to groundwater storage, observations should be investigated using field experiments. It is an indicator that can be used to estimate potential loss by mean of soil 5 hydraulic conductivity if a long period of time of the field measurement was undertaken. The relationship of penetrated water and testing period can be fitted using the simplest Kostiakov's model (Chow et al., 1988). The most common model for estimation of parameters is the water budget model.

This paper aims to contribute to the hydrological knowledge of a river reach within a 10 tropical floodplain, particularly the relations between the surface water and the phreatic surface of the river's interconnecting aquifer.

\section{Study area}

A 3-year programmed of water table monitoring and supplementary experiments were undertaken from the years 2001 to 2004 at Phopratabchang District, a paddy field area 15 was situated on floodplain of the Yom River in Phichit Province, Thailand (Fig. 1). The lower part of the main river is occupied by an extensive alluvial plain which flood usually occurs in this part during the rainy season from July to September corresponding to monsoon and typhoons effects. It is the typical season characterized by a pronounced long rainy season and produces around $90 \%$ of the annual rainfall amount. Its average 20 annual rainfall over the overall basin is $1434 \mathrm{~mm}$, and rainy day equals 80 days. The focused site covers an area of $153 \mathrm{~km}^{2}$ (inner zone in Fig. 1 and Fig. 2) lying on the west of the Yom River bounded by 3-local roads (no. 117 on the west, no. 1276 on the north, and no. 1070 on the south) and flood protection dikes (RID's dike on the east) which was chosen to conduct investigation of gains and losses from flood and 25 water table fluctuations. It was located in a larger basin $\left(1698 \mathrm{~km}^{2}\right)$ in Fig. 1 included 7 major catchments are namely Banglai, Dannoi, Huaipakwan, Lamnang, Rangnok, Saichanuanyai, and Thainam and 7 floodplain's catchments along the Yom River which

HESSD

2, 731-760, 2005

\section{Phreatic surface fluctuations within the tropical floodplain}

S. Chuenchooklin et al.

\section{Title Page}

\section{Abstract}

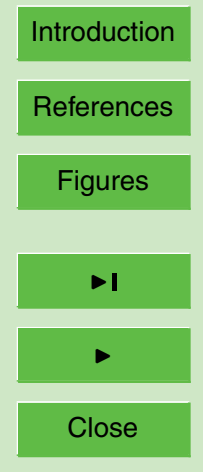

Back

Close

Full Screen / Esc

Print Version

Interactive Discussion 
was lying between 2 sites of observed river stages belonging RID (Royal Irrigation Department) namely Y17 (Samngam) at upstream and Y5 (Phothale) at downstream with the river length between those 2 stages of $71880 \mathrm{~km}$.

The inundated area occupies by some $50 \%$ of the inner area $\left(153 \mathrm{~km}^{2}\right)$ in Fig. 3 5 which occurs by overbank flowing from the river and overland flow from upstream catchment's runoff (Fig. 2). Moreover, its topography is very flat with average ground surface level of $+32.88 \mathrm{~m}$ above mean sea-level (MSL) and average slope of 0.000138 . There are 3-local streams flowing through this area and connecting to the Yom river namely Phairob (catchment's area of $74 \mathrm{~km}^{2}$ ), Nongkla (catchment's area of $92 \mathrm{~km}^{2}$ ), and 10 Dongsualuang (catchment's area of $59 \mathrm{~km}^{2}$ ) with average stream slope of 0.000286 . The streams have regulated structures namely Dannoi, Saichanuanyai, and Lamnang near the river's confluences, respectively.

Its geomorphology conforms by shallow clay or silt at the ground surface as the top layer and thick sand layer as unconfined aquifer beneath the top soil (Fig. 3). The effec15 tive porosity $\left(\eta_{e}\right)$ of this aquifer was averaged to 0.083 (Mekpruksawong et al., 2004). There were 22-observation wells (OW) ranged 15-30 m depth which was constructed by KTU (Kyushu Tokai University, Japan) and RID (Royal Irrigation Department) to monitor the change of phreatic surface levels (GWL) every $10 \mathrm{~min}$. Some 15-OWs lying on floodplain $\left(50.414 \mathrm{~km}^{2}\right)$ were namely P3, P7, P8, P9, P10, P11, P12, P13, P14, $\mathrm{P} 15, \mathrm{P} 20, \mathrm{P} 21, \mathrm{P} 22, \mathrm{P} 23$, and $\mathrm{P} 24$, respectively. Moreover, there was a river stage (Dlog) lying at the right bank of the Yom river upstream of Phopratabchang Bridge in order to recorded the change of daily river water level (RWL).

High-yield-variety (HYV) paddy ( $86 \%$ of total area) was grown 2 times a year. There were many shallow groundwater wells drilled and groundwater is utilized as supplementary water requirement for crop. The cropping pattern is shown in Fig. 4.

HESSD

2, 731-760, 2005

\section{Phreatic surface fluctuations within the tropical floodplain}

S. Chuenchooklin et al.

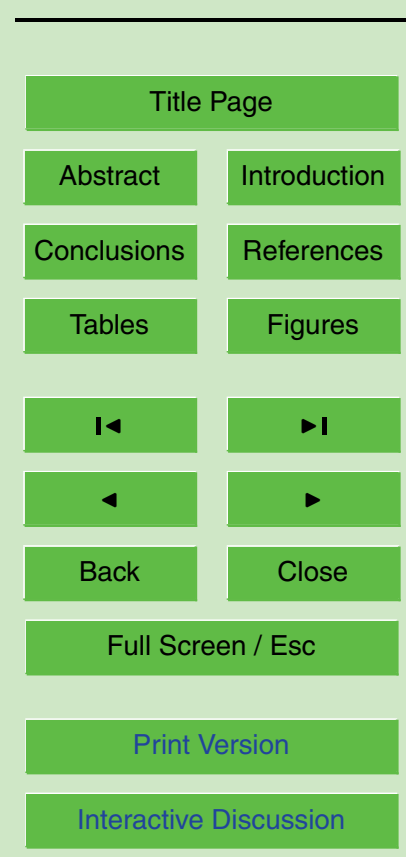




\section{Material and methods}

3.1. Topographical map and conceptual model

Unfortunately, due to lack of topographical data, contour-lines were constructed based on available data which were collected from RID, Highway Department (HWD), Royal

5 Thai Survey Department (RTSD), Department of Land Development (DLD), and Department of Environmental Quality Promotion (DEQP) and geographic information systems (GIS)'s maps with 1:50000 scale. The existing ground surveyed was done during the construction of OWs. Moreover, the inundated mapping was sketched using aerial and satellite imaging maps which used to verify those contour-lines. The re10 lations among inundated extents versus pool levels were plotted which used to estimate daily flooded storage changed. This paper applied Arc-View's GIS and surface programs as the tools for plotting those contour-lines and flood extensive over floodplain. The conceptual blocks model was applied using Thiessen's polygon for drawing each OW's serviced area (Fig. 5) which were used for infiltration and phreactic surface changes estimation by applying the water budgeting equations. The overall floodplain area $\left(50.414 \mathrm{~km}^{2}\right)$ was bounded by surrounding roads with the average ground surface elevation of $32.88 \mathrm{~m}$ (MSL). Most land-uses in this area is paddy $(89.6 \%)$, others were residential areas included upland crop and orchard (7.4\%), and water body and bare land $(3.0 \%)$.

\section{$20 \quad 3.2$. Model description and existing parameters}

The water budget model for studying surface and subsurface waters over the considered floodplain was applied (Fig. 6). The losses by infiltration (I) and evapotranspiration $(E T)$, and inundated extensive over the catchment's area were models within 3 categories: 1) non-flooded (upland), 2) semi-flooded, and 3) fully flooded (lowland). Firstly, 25 if the value of effective rainfall $\left(P_{e}\right)$ was less than the amount of infiltration capacity during the same period of time, then there was no flood occurred and upper soil surface

\section{HESSD}

2, 731-760, 2005

\section{Phreatic surface fluctuations within the tropical floodplain}

S. Chuenchooklin et al.

\section{Title Page}

\section{Abstract}

Introduction

Conclusions

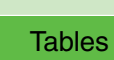

References

Tables

Figures

14

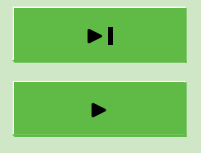

$\triangleleft$

Back

Close

Full Screen / Esc

Print Version

Interactive Discussion 
would be unsaturated. The actual infiltrating water would be equaled to such effective rainfall value and would be flown downward as gaining as raising water table in such considered block. Secondly, in case of continuing rainfall and infiltration with less than the amount of effective rainfall, then flood extensive would be occurred over the consid5 ered block. For both cases, the daily river water stage in the Yom River was less than the ground surface elevation (upland). Thirdly, if the river water level (RWL) was higher than ground surface elevation and the riverbank or levee (floodplain), flood discharge could be estimated as the flow over broad crested weir. The flood extensive would be occurred on a consequence of the RWL. The actual potential infiltration capacity could 10 be the rate of final infiltration value that nearly equaled to the rate of hydraulic conductivity $(K)$ because of ground surface was saturated. The keeping water depth in paddy field in each block during growing season was averaged by $0.05 \mathrm{~m}$ with $0.02-0.08 \mathrm{~m}$ in variant. However, during wet season and flood period, depth of water above ground was varied and ranged from 0.2 to $3.0 \mathrm{~m}$. The amount of infiltration would be varied by head of water according to Darcy's Law as the rate of seepage.

In case of none flooded (Fig. 7), the continuity equation for the hydrological processes measured over a certain period of time $(t)$ will be budgeted as:

$I=(P-E T)+\left(Q_{\text {in }}-Q_{\text {out }}\right)-\Delta S$

$P-E T$ can be considered as effective rainfall volume $\left(P_{e}\right)$. Whereas $Q_{i n}$ is the total 20 volume of upstream runoff water from every lateral streams and over-bank flow from the river, $Q_{\text {out }}$ is the total volume of runoff water flow out from the considered downstream boundary through the regulators at the end of lateral streams, I is the infiltration or seepage volume, and $\Delta S$ is the change of storage volume. The stream discharges via those regulated structures will be considered as the flow volume via their channels.

25 For the case of flooded, it is assumed that there is no any plant grown in such period, and then $E T$ can be considered as existing evaporation $(E)$. The extra-inflow $\left(Q_{i n}\right)$ can be computed as the discharge across the levee or roads along the river.

The total amount of infiltrated water from surface to subsurface of the 3-cases over the year will be recharged to the unconfined aquifer and increased phreatic surface

HESSD

2, 731-760, 2005

\section{Phreatic surface fluctuations within the tropical floodplain}

S. Chuenchooklin et al.

\section{Title Page}

\section{Abstract}

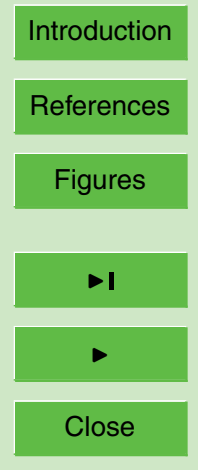

Back

Close
Full Screen / Esc

Print Version

Interactive Discussion 
level during inundated period. However, during growing season, if rainfall is less than crop water requirement withdrawal of groundwater from shallow wells will be occurred which affects the recessing of phreatic surface levels.

The first parameter, $P$, was the weighted values from actual daily rainfall amount at 5 every rain gauge which was estimated by the Thiessen polygons method which located at the districts namely Phichit, Samngam, Saingam, Phopratabchang, Phothale, and Kanuworalaksaburi. There was an automatically rain gauge with 5-min time interval recorded and located at Neonkwang School (P3) in the middle part of the inner zone. It was used for the study of rainfall intensity-duration-frequency and surface runoff over 10 the catchments.

To estimate crop water requirement $\left(E T_{c}\right)$, the FAO's potential evapotranspiration $\left(E T_{o}\right)$ using combined Penman-Monteith's (P-M) equation (Doorenbos et al., 1977) was applied. Whereas all parameters for this equation were applied by using standard climatologically data recorded by the MD (Thai Meteorological Department) at the 15 Phichit Agricultural Research Station in Phichit Province. Those included daily solar radiation (sunshine hour), air temperature (maximum and minimum), humidity and wind speed data. Then $E T_{C}$ for each kind of crop during growing season in none flooded catchments could be estimated as $E T_{o}$ multiplied by crop coefficients $\left(K_{c}\right)$ at each growing stages which assumed to be the amount of groundwater consumed.

The loss from surface water was considered as flux over the catchments $(/)$ getting from field infiltration experiment using ring-infiltrometer and fitted by empirical Kostiakov's infiltration model. The accumulated depth into the soil $(D)$ versus recording times $(t)$ would be equaled to the amount of infiltrated water $(F)$. However, during the saturated condition or longer time of infiltration has been taken, $F$ can be replaced by 25 saturated hydraulic conductivity $(K)[\mathrm{mm} / \mathrm{d}]$ varied by head. The seepage coefficient $\left(A_{c}\right)[\mathrm{mm} / \mathrm{d} / \mathrm{m}]$ was introduced as the rate of infiltrated per head of ponded water above the ground surface (Mekpruksawong et al., 2004).

$A_{c}=K / H$

The results of field infiltration would be weighed by Thiessen Polygon's area of each 737

HESSD

$2,731-760,2005$

\section{Phreatic surface \\ fluctuations within \\ the tropical \\ floodplain}

S. Chuenchooklin et al.

\section{Title Page}

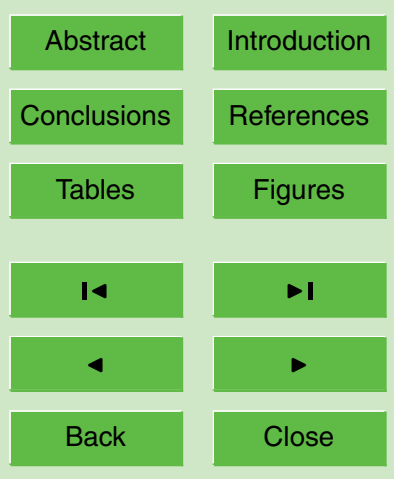

Full Screen / Esc

Print Version

Interactive Discussion 
observation well to represent the spatially distribution of fluxes and $A_{c}$ over the catchment's area.

To estimate lateral inflow $\left(Q_{i n}\right)$ from upstream sub-catchments entering the inner zone, the method of ungauged basin with lack of rainfall and stream flow data was 5 applied using the neighboring catchment's data of topographical and watershed characteristics. The synthetic hydrograph using Snyder and US Army Corps of Engineers method (US.ACE, 1994; Chow et al., 1988) was applied to compute the peak discharge $\left(q_{p}\right)$ and the hygrograph shape. The basin characteristics including the stream length $(L)[\mathrm{km}]$, stream length measure from the centered of basin to outlet point $\left(L_{c}\right)[\mathrm{km}]$, 10 average stream slope $(S)$, catchment's area $(A)\left[\mathrm{km}^{2}\right]$, effective rainfall $\left(P_{e}\right)[\mathrm{mm}]$ and $C_{t}, C_{p}, a_{1}, a_{2}$ getting from those relationships in linear regression from the neighboring basins were applied to compute the peak discharge, lag-time from the duration of rainfall to the peak discharge $\left(t_{p}\right)[\mathrm{h}]$, and base time $\left(t_{b}\right)$. Therefore, lateral inflows $\left(Q_{i n}\right)$ and their hydrographs entering the inner zone could be sketched. However, the extra ${ }_{15} Q_{i n}$ that might be spilled out from the river across the levee or road along the river entering the inner zone with length of $3.95 \mathrm{~km}$ and altitude of $33.58 \mathrm{~m}$ (MSL) during flood season. $Q_{\text {out }}$ as discharge via the open channel of the streams, road structures, and tail regulators was considered (Chow et al., 1988).

The area of flood extensive over the floodplain was studied according to daily river 20 stage recorded at the middle reach of the Yom River (Dlog). Moreover, occasional field water stage observation during flood period at the upstream boundary (Wangjik) along the main road (Rd.\#1276) through the feeder roads and observation wells in the inner zone and down to the last section at downstream boundary (Phaitapho) along the other main road (Rd.\#1070) was investigated and used to sketch the water surface profiles.

25 Therefore, the relationship among flooded height above natural ground surface versus inundated area and temporary flood storage would be fitted. Due to the limitation of the numbering of observation points in floodplain, the assumption of water surface level at every point along each cross sectional profiles would be the same value as the river water surface level (RWL). Therefore, flood flow patterns could be presented

HESSD

2, 731-760, 2005

\section{Phreatic surface \\ fluctuations within \\ the tropical \\ floodplain}

S. Chuenchooklin et al.

\section{Title Page}

\section{Abstract}

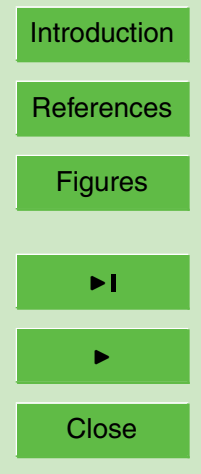

Back

Close

Full Screen / Esc

Print Version

Interactive Discussion 
at each return period of flood occurrences using the Gumbel's distribution. Then the inundated depth at any point along floodplain cross-section would be used as flux head in the infiltration model and used to study the change of phreatic surface level (GWL). Moreover, the standard-step method in the river hydraulic analysis's HEC-RAS model 5 (US.ACE, 2001) was applied during the first year that without the stage recorder at Dlog yet. The cross-sectional profiles with average step length of 5-6 km which the upstream boundary water level at $Y 17$ was used as initial condition and for computing stages along the Yom River at cross-sectional profiles, through the inner zone and down to the last section at $Y 5$.

10 The change of phreatic surface levels in sub-surface water part (Fig. 7) would be compared to the computed recharge over the effective porosity. The effects from lateral groundwater inflow $\left(G W_{i n}\right)$ and outflow $\left(G W_{\text {out }}\right)$ from adjacent blocks and leakage to the lower aquifer might affected the change of phreatic surfaces which could be further computed using Darcy's equation based on the change of the slope of the water table between the blocks (Mekpruksawong et al., 2004).

\section{Results and discussions}

The summary of the configuration of 15-OW Thiessen blocks are namely P03, P07, P08, P09, P10, P11, P12, P13, P14, P15, P20, P21, P22, P23, and P24, and 49-field infiltration points (Fig. 5) were shown in Table 1. These included the serviced area $(A)$ 20 of each OW, ground elevation, $F, A_{c}, K$ whereas the isohyets of field $A_{c}$ before block averaging was presented in Fig.8. The final infiltration (approx. $K$ ) in the upstream basins connecting the inner zone $\left(153 \mathrm{~km}^{2}\right)$ was averaged to 9.386 and $3.375 \mathrm{~mm} / \mathrm{d}$ for the first day and longer period (30 days) of ponded water, respectively. The average infiltration rate $\left(F_{a v g}\right)$ and time relationships in Kostiakov's model was shown to be 25 $F=9.386 t^{-0.3007}[\mathrm{~mm} / \mathrm{d}]$ with $R^{2}=0.9947$. The initial infiltration $(F)$, however, in the inner zone $\left(50.414 \mathrm{~km}^{2}\right)$ was averaged $4.925 \mathrm{~mm} / \mathrm{d}$ and the final infiltration in the floodplain zone was $1.355 \mathrm{~mm} / \mathrm{d}\left(1.568 \times 10^{-6} \mathrm{~cm} / \mathrm{s}\right)$ with $A_{C}$ of $16.245 \mathrm{~mm} / \mathrm{d} / \mathrm{m}$ of head

\section{HESSD}

$2,731-760,2005$

\section{Phreatic surface fluctuations within the tropical floodplain}

S. Chuenchooklin et al.

\section{Title Page}

Abstract

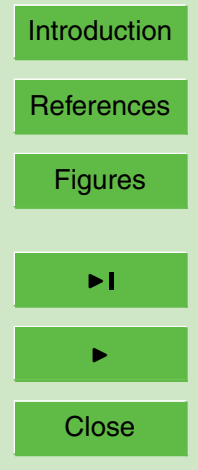

Back

Close

Full Screen / Esc

Print Version

Interactive Discussion 
of ponded water (Table 1).

The 4-years daily data recorded of $P$ and elevation of river water stage (Fig. 9) was shown that flood peak in 2001 was less than flood in 2002 which was highest peak. The comparison between $P, E T_{o}, F$, and runoff in the inner zone from the 5 upstream boundary at Wangjik via Dlog to the downstream boundary at Phaitapho were presented in daily (Fig. 10) and annually (Fig. 11) with annual $P$ of $1103.6 \mathrm{~mm}$, $E T_{o}$ of $1515.8 \mathrm{~mm}, F$ at the upstream area of $723.1 \mathrm{~mm}(69.14 \%$ of annual rainfall), $Q_{i n}$ from upstream basins $\left(225.137 \mathrm{~km}^{2}\right)$ entering the inner zone of $634.2 \mathrm{~mm}(57.5 \%$ of annual rainfall. Whereas the mean daily of $E T_{o}, F$ were equaled to $4.15,2.12 \mathrm{~mm}$, 10 respectively.

The average characteristics and results of Snyder's synthetic unit hydrographs for 3subbasins in the inner zone were; the average slope of 0.000286 , unit discharge $\left(q_{p}\right)$ of $1.788 \mathrm{cu} . \mathrm{m} / \mathrm{s} / \mathrm{mm}$, and lag time $\left(t_{p}\right)$ of $12.3 \mathrm{~h}$, respectively. The local stream discharge was very small compare to the river and floodplain flow that will not affect the flood 15 extent. However, it contributed and combined to the overbank flow from the Yom River during inundated period.

The characteristic of flooded elevation, inundated extent, and temporary storage volume between Wangjik to Phaitapho was presented (Fig. 12). The result of flood extent was used to draw flood flow patterns in Fig. 13 (Chuenchooklin et al., 2003) and com20 parative of inundated extent in 3-years (Fig. 14). The comparison between RWL and GWL was presented in Fig. 15 and Fig. 16. The lag-time between rising and recession limbs of those hydrographs in the year 2002 and 2003 were 75 days and 105 days (during rising limb), and 10 days and 6 days (during recession limb), respectively. Those trend lines in Fig. 16 during rising and recession limbs were fitted with $R^{2}$ equal to 0.90 (Chuenchooklin et al., 2004). The difference on slope of those trend lines and time delayed during rising and falling limbs were shown because of flood volume and ponded time in the year 2002 was more and longer than in the year 2003. However, the data of water table hydrographs of some OWs along the river e.g. P20, P22, and P24 were less affected by the change of river water levels.

HESSD

2, 731-760, 2005

\section{Phreatic surface \\ fluctuations within \\ the tropical \\ floodplain}

S. Chuenchooklin et al.

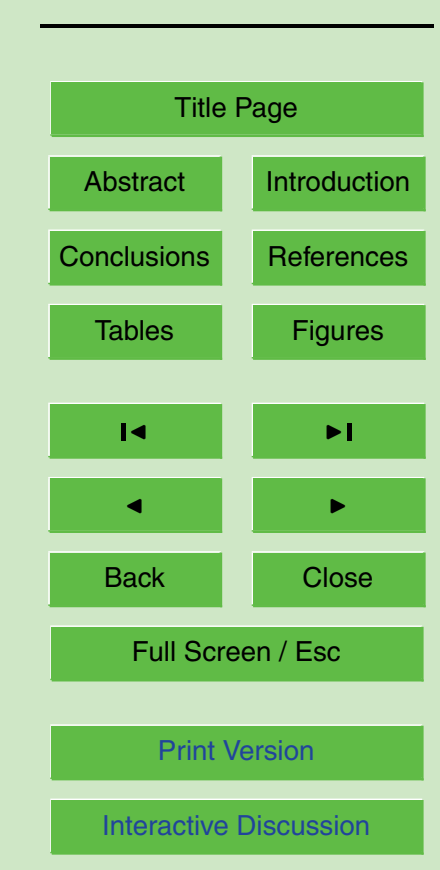

EGU 
The computation of recession constant $\left(K_{r b}\right)$ for baseflow separation into groundwater flow $\left(K_{r g}\right)$ and interflow $\left(K_{r i}\right)$ during the years 2000-2003 were fitted average of 0.783 and 0.936 , respectively and $R^{2}=0.9672$. The amount of annual baseflow per total runoff via the measuring point was averaged to 0.107 . However, during dry sea-

5 son (January to May), there is no baseflow in the river because of the withdrawal for crop and human consumption has been taken by farmers and communities using small pumping machines along the river. Therefore, the baseflow is decreasing as the result showed that the trend line of the minimum GWL in dry season (P7, P11, and P14) is slightly decreasing with the rate of $0.10 \mathrm{~m}$ per year (Fig. 15).

The simulation using water budget for each polygon showed that the averaged losses rate from paddy field percolated to the uppermost aquifer layer was very high with $2650 \mathrm{~m}^{3} / \mathrm{d} / \mathrm{km}^{2}$. Total annually infiltrated water was 26 million $\mathrm{m}^{3}$ during inundated period (90 days) in year 2002 over floodplain paddy field area $\left(50.414 \mathrm{~km}^{2}\right)$ with about $5730 \mathrm{~m}^{3} / \mathrm{d} / \mathrm{km}^{2}$. The averaged daily P-M's $E T_{o}$ was $4.1 \mathrm{~mm}$ which produced the total 15 potential loss by this phenomenon and for dry seasonal crop water requirement computing of 34 million $\mathrm{m}^{3}$ with about $75 \%$ of gross area.

\section{Conclusions}

From the study using water budget model, the distributions of infiltration fluxes over floodplain have a directly effect to the phreatic surfaces through flood extent over the land surface during inundated period. The daily flood storage and inundated area in the study site could be estimated from the corresponding local lateral inflows, overflow from the bank-full level. The generated database from existing topographic contours and basin characteristics using GIS techniques coupling to hydrologic models could be applied to compute flood. Most of the floods were produced by overflowing from the riverbank because of total sub-catchments area were smaller than whole river basin sizing. Flood risk map could be developed corresponding to hydrological statistics, and hydrodynamic model, should be extended to the local administration officers and

HESSD

2, 731-760, 2005

\section{Phreatic surface fluctuations within the tropical floodplain}

S. Chuenchooklin et al.

\section{Title Page}

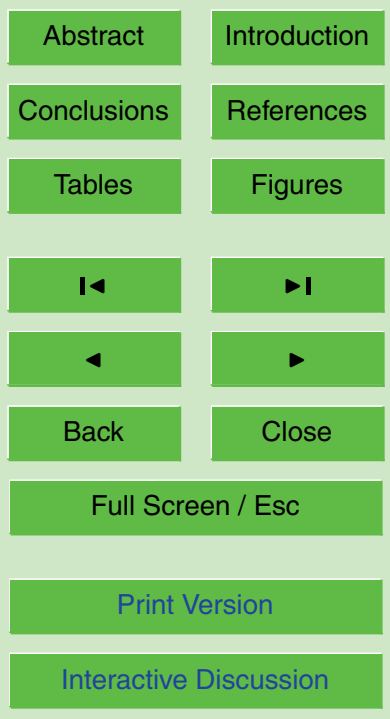

EGU 
farmers in order to change or shift cropping pattern in floodplain for avoiding flood.

The main cause of inundated extent in this study area was over-bank flow from the river rather than the flow from surface runoff over its catchment's area. The influences from inundated zone leaded to the increasing of phreatic surface too. If higher inun5 dated depth by flood occurred then the slope-line of GWL on the rising limb would be steeper than fewer floods which were already discussed on Fig. 15 and Fig. 16. On the other hand, the downward slope of trend line of GWL occurs which might be influenced by the greater amount of groundwater withdrawal than amount of flood recharging. The fluctuation of phreatic surface was mainly influenced by flooded recharge and ground10 water withdrawal. For the conservation of phreatic surface in flooded zone, further study about flood reduction through artificial recharge from the zone with high infiltration flux e.g. farm-ponds and sandpits should be carried out. Understanding and quantifying the phreatic surface fluctuations in lowland paddy field is crucial for further floodplain management.

15 Acknowledgements. The authors wish to thank the following institutions for supporting this research program: the Graduate School Khon Kaen University, Naresuan University, Kyushu Tokai University, King Mongkut Institute of Technology at Lardkrabang, and the Royal Irrigation Department.

\section{References}

Chow, V. T., Maidment, D. R., and Mays, L. W.: Applied Hydrology, McGraw-Hill International Editions, 1988.

Chuenchooklin, S., Ichikawa, T., and Patamatamkul, S.: Flood flow pattern and distribution of infiltration over large floodplain and natural groundwater recharge area, Annual Journal of Hydraulic Engineering, JSCE, 47, 211-216, 2003.

25

Chuenchooklin, S., Ichikawa, T., and Patamatamkul, S.: The effect of flood changes on phreatic surface in large floodplain in Phichit, Proceedings: 2nd APHW Conference, 5-8 July 2004, Singapore, Vol. 1, 32-42, 2004.

HESSD

2, 731-760, 2005

\section{Phreatic surface fluctuations within the tropical floodplain}

S. Chuenchooklin et al.

\section{Title Page}

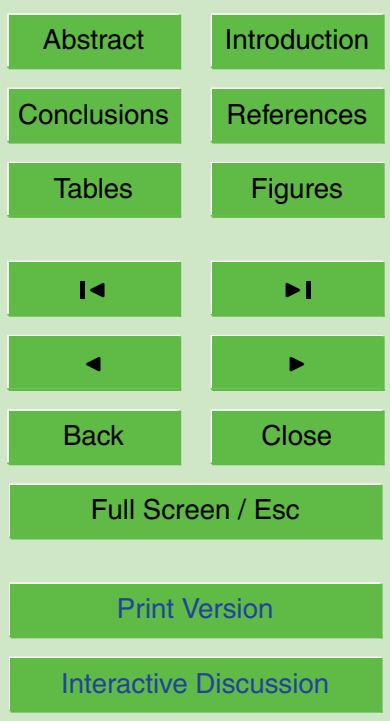

EGU 
Doorenbos, J. and Pruitt, W. O.: Guidelines for lease predicting crop water requirements, FAO Irrigation and Drainage Paper, Vol. 24, 1977.

Ichikawa, T., Mekpruksawong, P., Chuenchooklin, S., Aramaki, S., and Patamatamkul, S.: Groundwater and irrigation problem in flood Chaophraya river basin: in case of Phichit study area, Proceedings: 14th Asian agricultural symposium on environmental management for resource conservation, 9-10 December 2004, Chiengmai, Thailand, 1, 83-99, 2004.

Mekpruksawong, P., Ichikawa, T., Aramaki, S., and Yamada, T.: Hydrogeological condition and groundwater behavior in low land, Thailand, J. Japan Soc. Hydrology \& Water Resources, 17, 1, 32-42, 2004.

U.S. Army Corps of Engineers (US.ACE): Flood-Runoff Analysis, Engineering and design, Engineer Manual no. EM 1110-2-1417, 1994.

U.S. Army Corps of Engineers: HEC-RAS River analysis system: Hydraulics reference manual version 3.0, retrieved from http://www.hec.usace.army.mil, Public distribution unlimited, 2001.

\section{HESSD}

2, 731-760, 2005

\section{Phreatic surface \\ fluctuations within \\ the tropical \\ floodplain}

S. Chuenchooklin et al.

\section{Title Page}

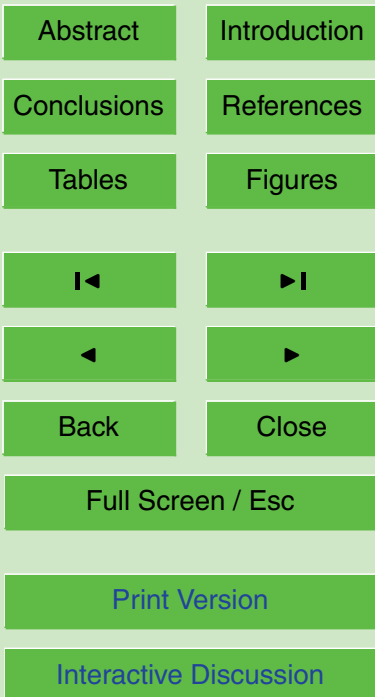




\section{HESSD}

2, 731-760, 2005

Table 1. Summary of 15-observation well (OW)'s configuration resulted by Thiessen Polygon.

\begin{tabular}{cccccc}
\hline OW's name & $A\left[\mathrm{~km}^{2}\right]$ & Elevation $[\mathrm{m}(\mathrm{MSL})]$ & $F[\mathrm{~mm} / \mathrm{d}]$ & $A_{c}[\mathrm{~mm} / \mathrm{d} / \mathrm{m}]$ & $K[\mathrm{~mm} / \mathrm{d}]$ \\
\hline P03 & 4.233 & 33.727 & 12.4275 & 30.988 & 2.1328 \\
P07 & 0.623 & 33.675 & 0.0606 & 9.595 & 0.0033 \\
P08 & 3.968 & 33.824 & 2.7883 & 10.941 & 0.6015 \\
P09 & 3.350 & 34.074 & 0.8771 & 9.799 & 0.0372 \\
P10 & 3.674 & 33.455 & 13.2486 & 14.555 & 4.8885 \\
P11 & 3.704 & 33.160 & 3.9618 & 4.284 & 0.9247 \\
P12 & 2.248 & 32.126 & 3.9296 & 37.661 & 0.7095 \\
P13 & 3.182 & 33.546 & 3.4740 & 4.722 & 1.5381 \\
P14 & 4.356 & 32.744 & 3.8949 & 51.089 & 0.9424 \\
P15 & 4.825 & 32.570 & 7.6243 & 23.693 & 2.2082 \\
P20 & 3.653 & 31.626 & 2.8464 & 4.698 & 1.6496 \\
P21 & 2.814 & 32.198 & 9.6890 & 14.810 & 2.7641 \\
P22 & 2.297 & 32.080 & 0.2869 & 6.303 & 0.0225 \\
P23 & 5.922 & 32.166 & 0.9923 & 2.788 & 0.0415 \\
P24 & 1.566 & 32.370 & 0.2869 & 6.303 & 0.0225
\end{tabular}

Phreatic surface

fluctuations within

the tropical

floodplain

S. Chuenchooklin et al.

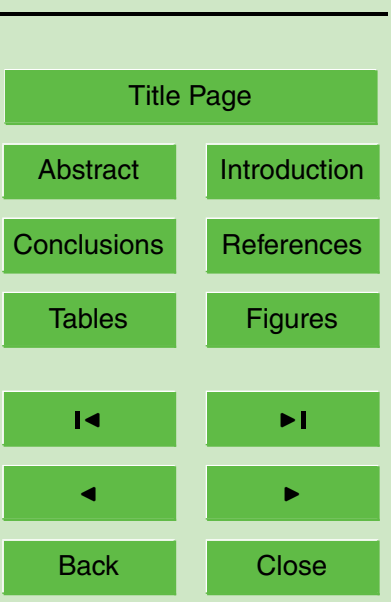

Full Screen / Esc

Print Version

Interactive Discussion 


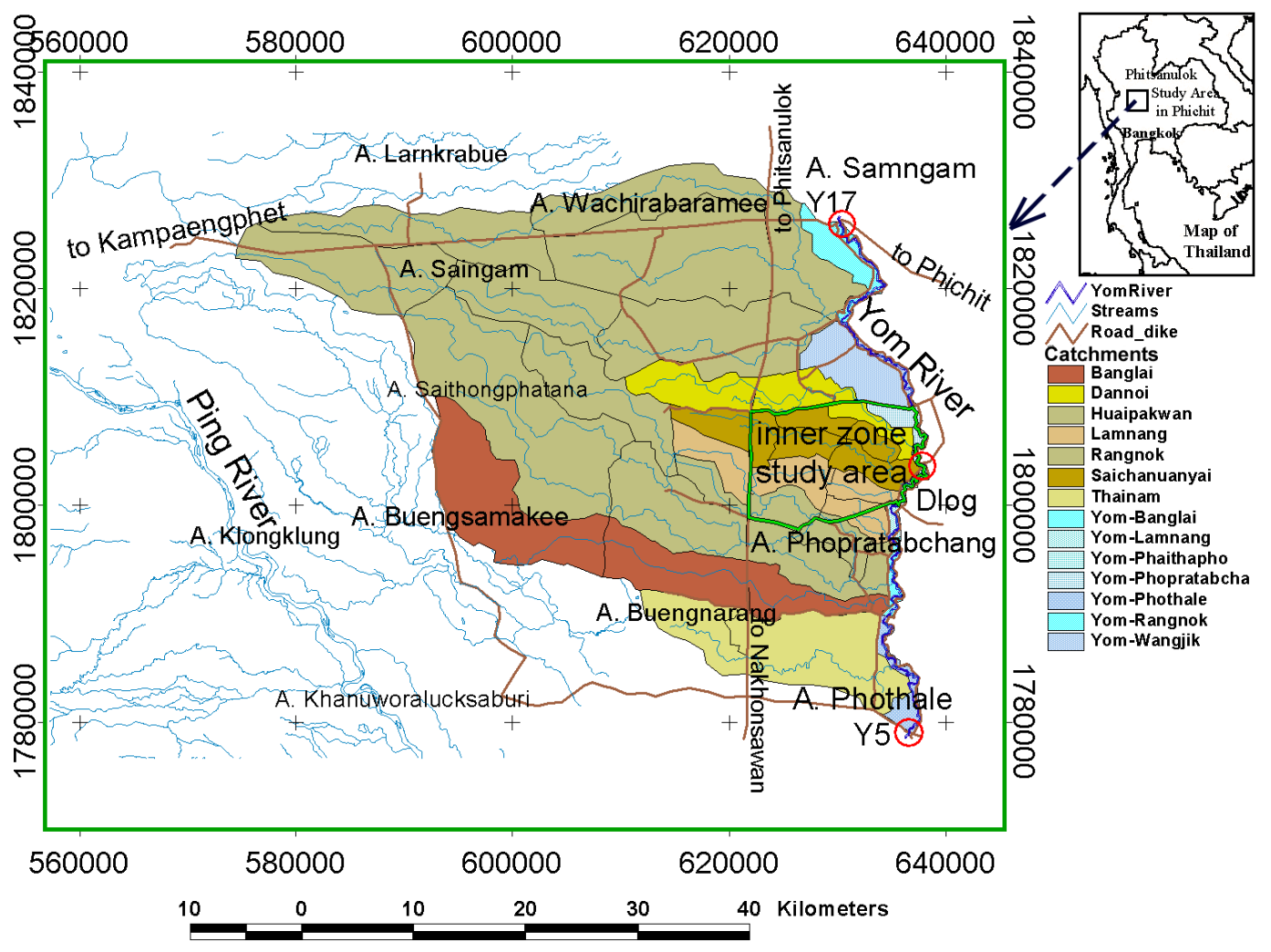

\section{HESSD}

2, 731-760, 2005

\section{Phreatic surface fluctuations within the tropical floodplain}

S. Chuenchooklin et al.

\section{Title Page}

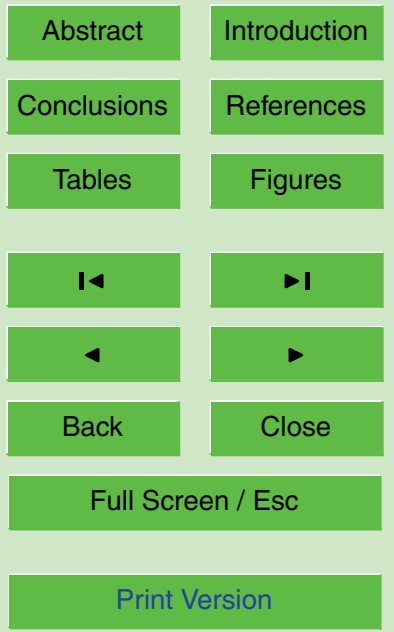
gauging stations.

Interactive Discussion 


\section{HESSD}

2, 731-760, 2005

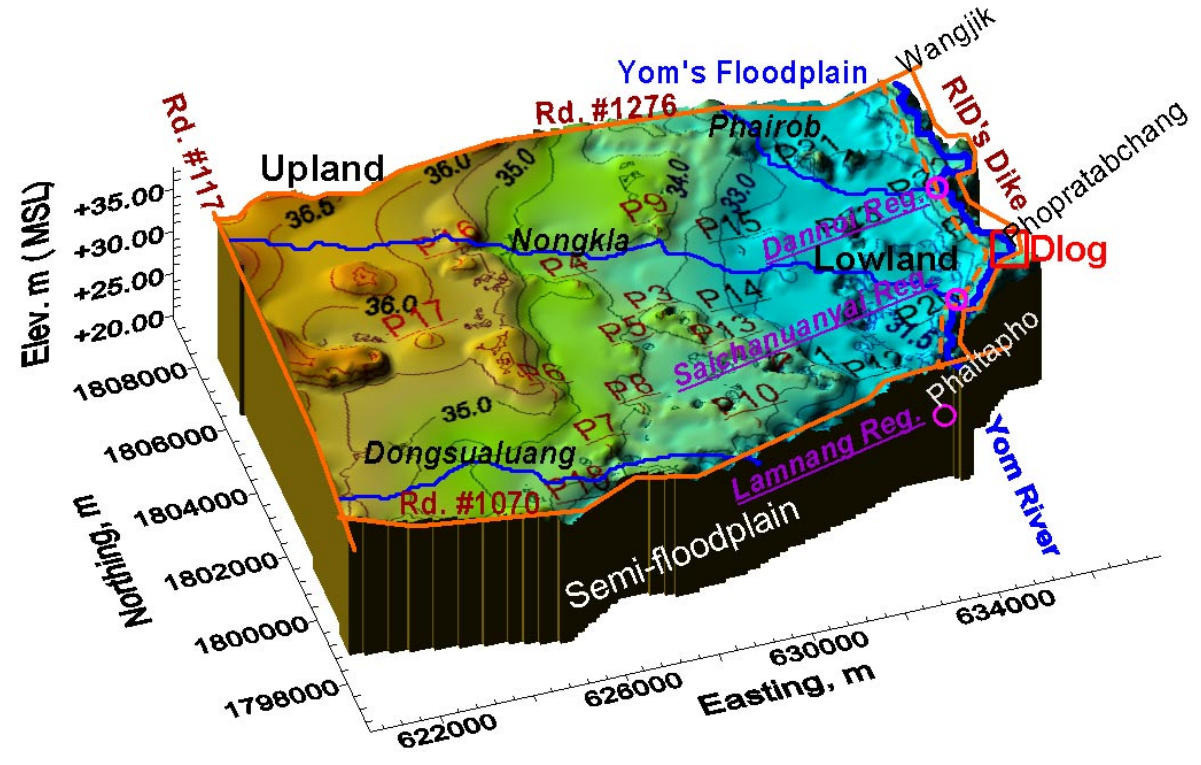

Fig. 2. 3-D view of the inner zone $\left(153 \mathrm{~km}^{2}\right)$ included contour-lines, roads boundaries, dike, Yom-River, 3-local streams (Phairob, Nongkla, and Dongsualuang) with regulated structures (Dannoi, Saichanuanyai, and Lamnang), location of river stage recorder (Dlog) and 22observation wells (P3 to P24).

\section{Phreatic surface fluctuations within the tropical floodplain}

S. Chuenchooklin et al.

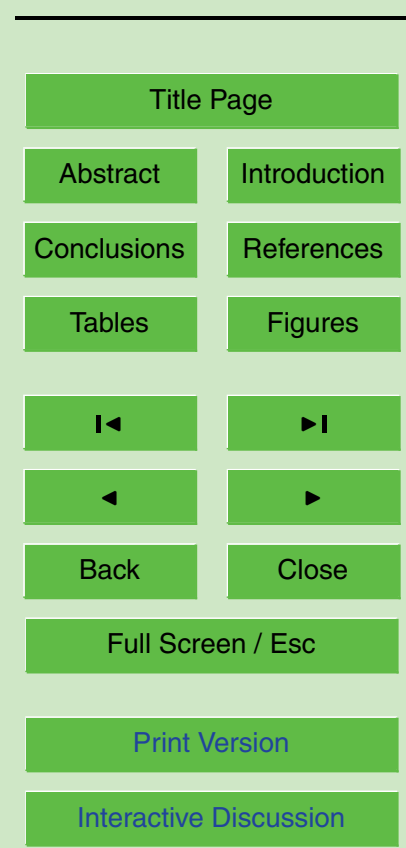




\section{HESSD}

2, 731-760, 2005

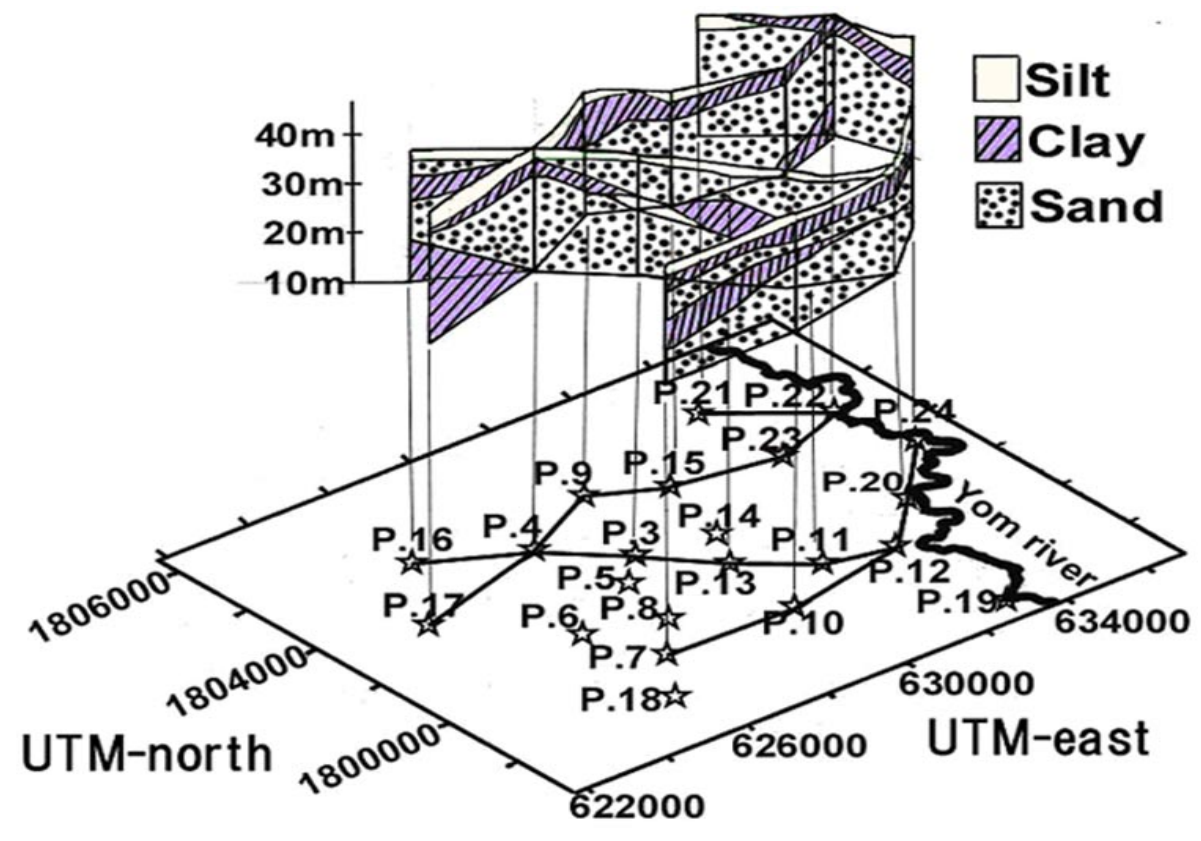

Fig. 3. 3-D view of geological profiles resulted by soil log data interpreting from 22-observation wells (OW)'s construction in the inner zone (after Mekpruksawong et al., 2004).
Phreatic surface

fluctuations within

the tropical

floodplain

S. Chuenchooklin et al.

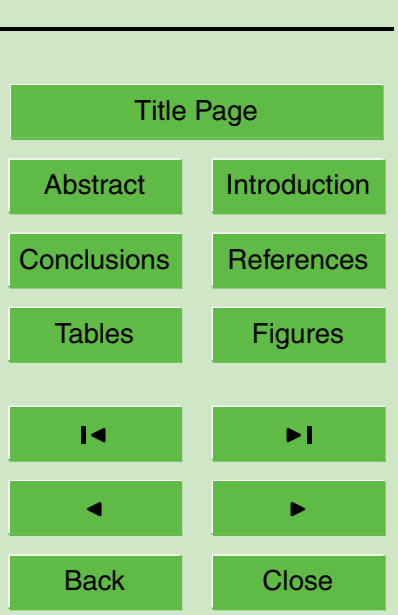

Full Screen / Esc

Print Version

Interactive Discussion 


\section{HESSD}

2, 731-760, 2005

\section{Phreatic surface fluctuations within the tropical floodplain}

S. Chuenchooklin et al.

\begin{tabular}{|c|c|c|c|c|c|c|c|c|c|c|c|c|}
\hline Type of crops & Jan & Feb & Mar & Apr & May & Jun & Jul & Aug & Sep & Oct & Nov & Dec \\
\hline A. HYV rice in lowland floodplain & \multicolumn{3}{|c|}{ HY-Rice\#1 } & & & \multicolumn{3}{|c|}{ HYV-Rice\#2 } & \multicolumn{3}{|c|}{ inundated area } & $\# 1$ \\
\hline B. HYV-rice in semi-floodplain & $\mathrm{HW}$ & Rice\#1 & 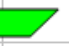 & & HW- & ice勒 & & & HW. & ice\#3 & & $\# 1$ \\
\hline c. Upland crops \& HYV-rice in up & & Ipland & crops & 7 & & & & & & -Rice & & \\
\hline
\end{tabular}

Fig. 4. Cropping pattern in the inner zone of study area.

Title Page

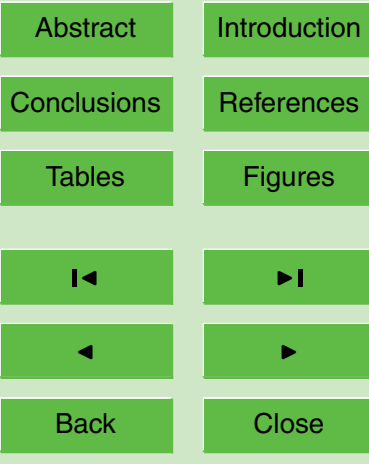

Full Screen / Esc

Print Version

Interactive Discussion 


\section{HESSD}

2, 731-760, 2005

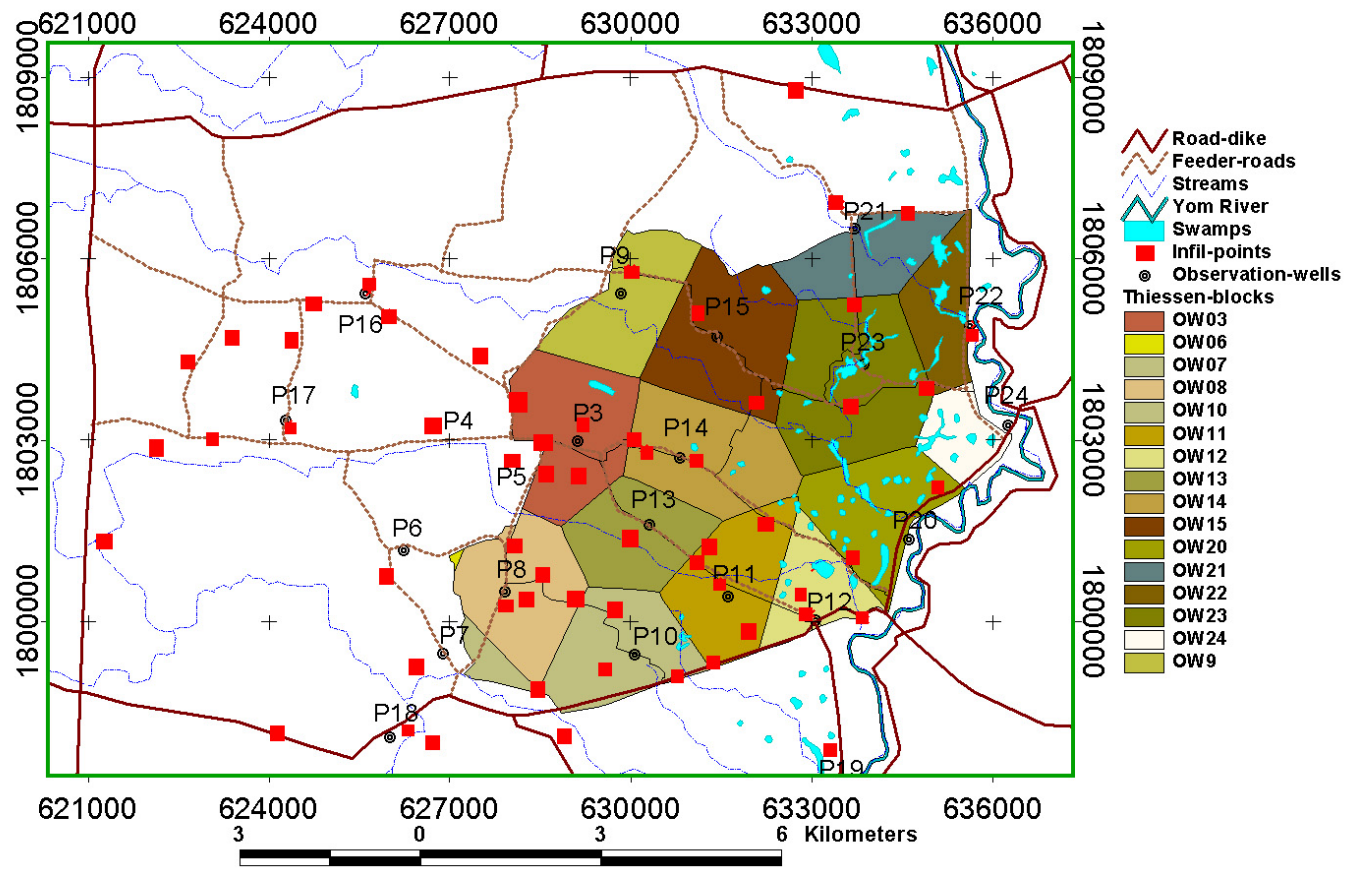

Phreatic surface

fluctuations within

the tropical

floodplain

S. Chuenchooklin et al.

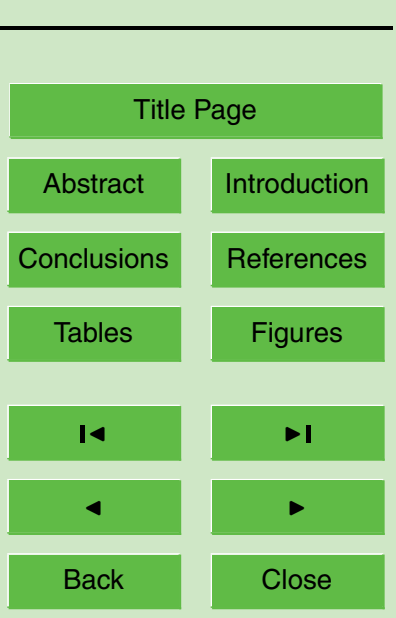

Full Screen / Esc

Fig. 5. View of 15-observation well's serviced area (OW) using Thiessen's polygon in study area $\left(50.414 \mathrm{~km}^{2}\right)$ and location of 49 -field infiltration experimental points located in floodplain.

Print Version

Interactive Discussion 


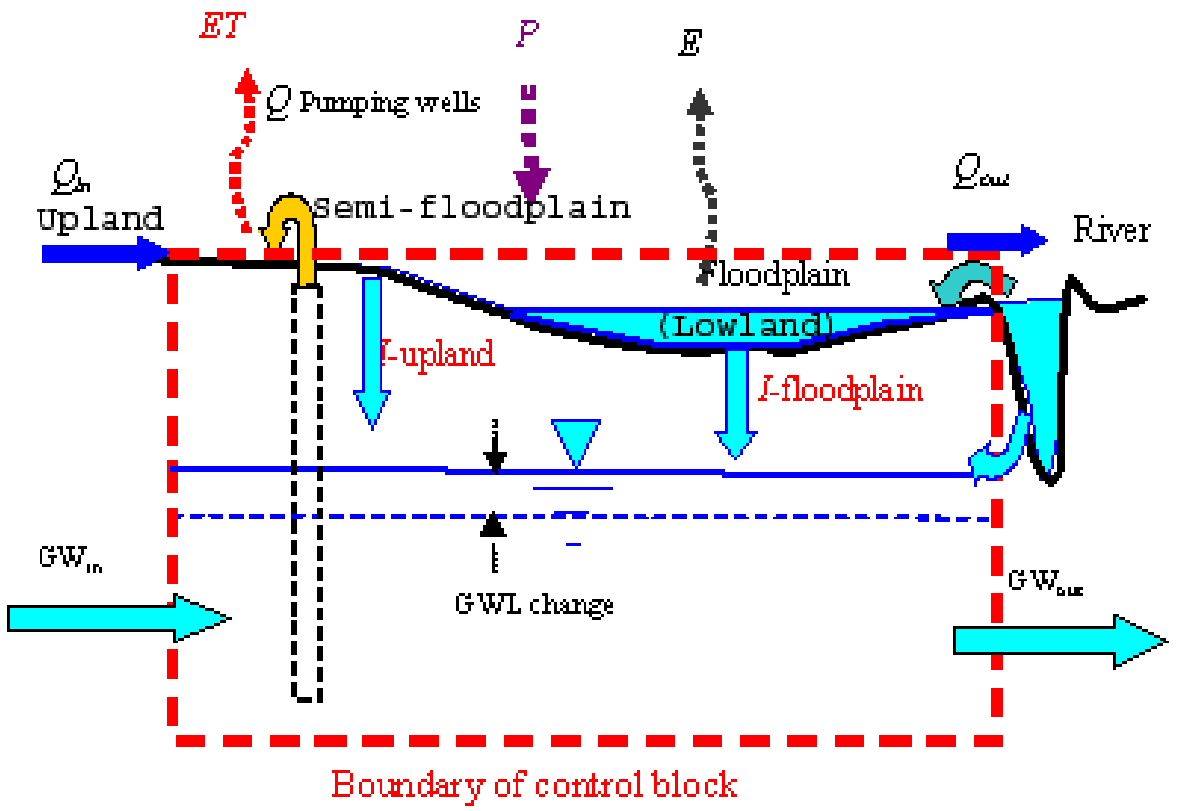

Fig. 6. Configuration of water budget model for the study interactions of floodplain-groundwater interactions.

\section{HESSD}

2, 731-760, 2005

Phreatic surface fluctuations within the tropical floodplain

S. Chuenchooklin et al.

Title Page

\begin{tabular}{|c|c|}
\hline Abstract & Introduction \\
\hline Conclusions & References \\
\hline Tables & Figures \\
\hline I4 & \\
\hline 4 & \\
\hline Back & Close \\
\hline
\end{tabular}

Full Screen / Esc

Print Version

Interactive Discussion 


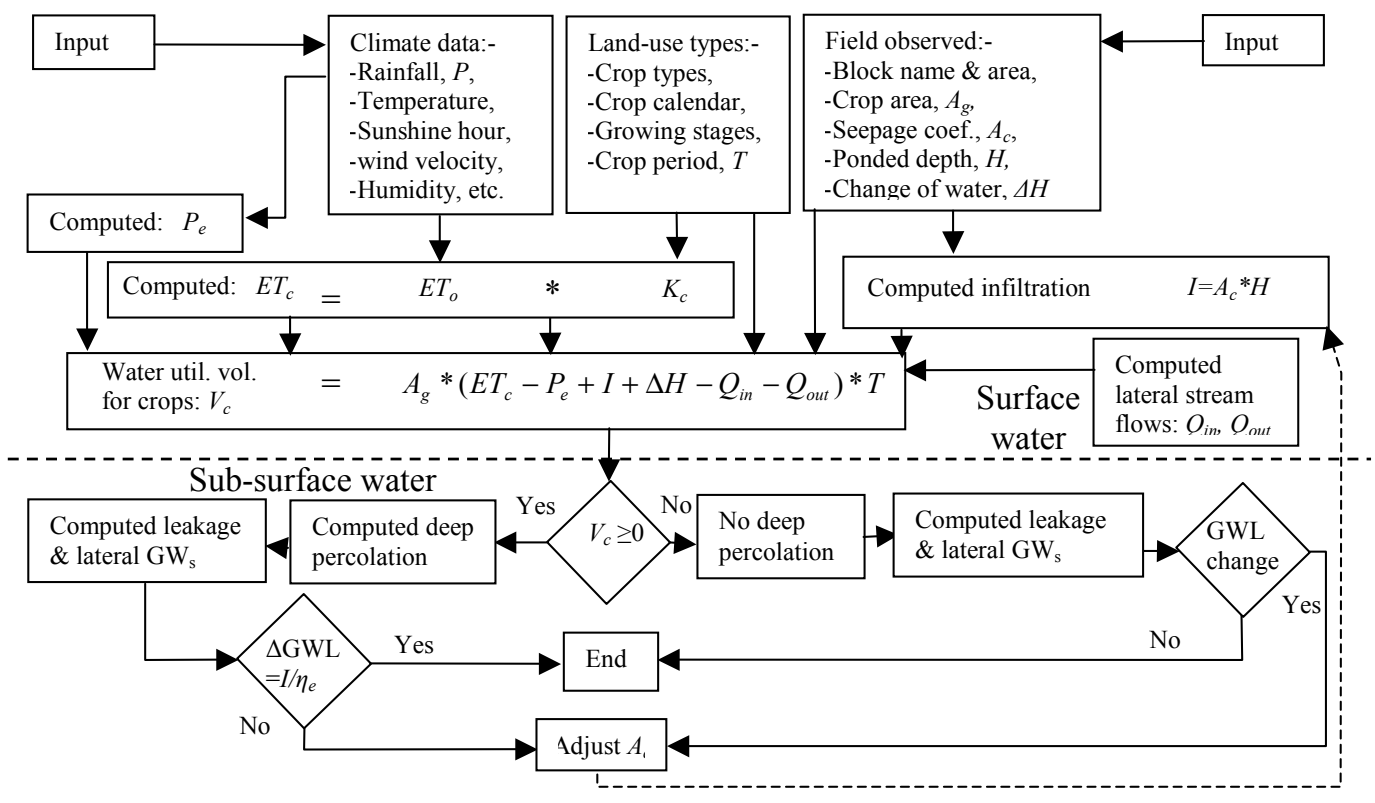

Fig. 7. Flow chart of computing the change of phreatic surface and ponding water in floodplain paddy field.

\section{Phreatic surface fluctuations within the tropical floodplain}

S. Chuenchooklin et al.

\section{Title Page}

\begin{tabular}{|c|c|}
\hline Abstract & Introduction \\
\hline Conclusions & References \\
\hline Tables & Figures \\
\hline I & \\
\hline & \\
\hline Back & Close \\
\hline Full Screen / Esc \\
\hline
\end{tabular}




\section{HESSD}

2, 731-760, 2005

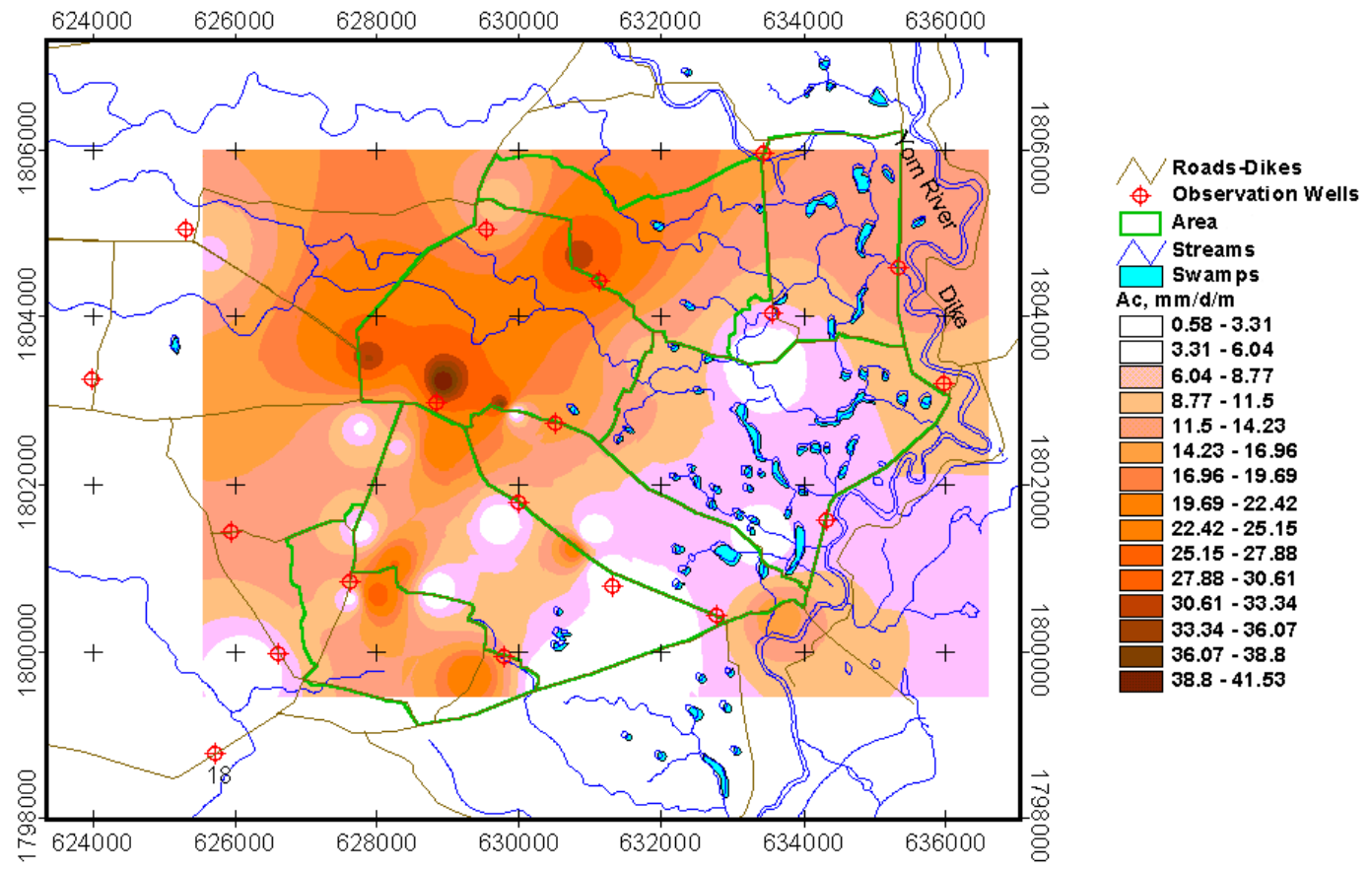

Phreatic surface

fluctuations within

the tropical

floodplain

S. Chuenchooklin et al.

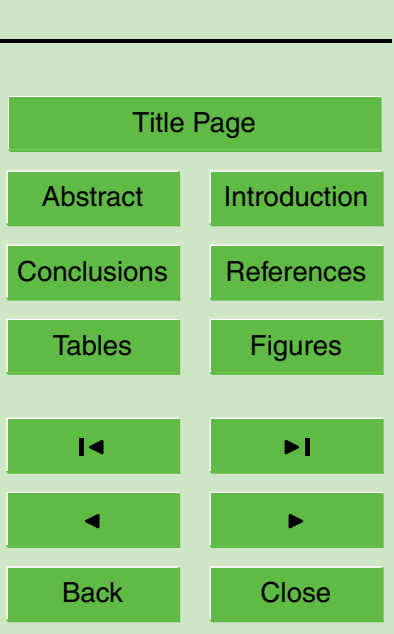

Full Screen / Esc

Fig. 8. The distribution of infiltration flux $\left(A_{c}\right)$ over floodplain resulted by 49 -points of field Print Version 


\section{HESSD}

2, 731-760, 2005

Rain-mean —Y17_Wangjik_ Dlog_ Avg. Rain30d

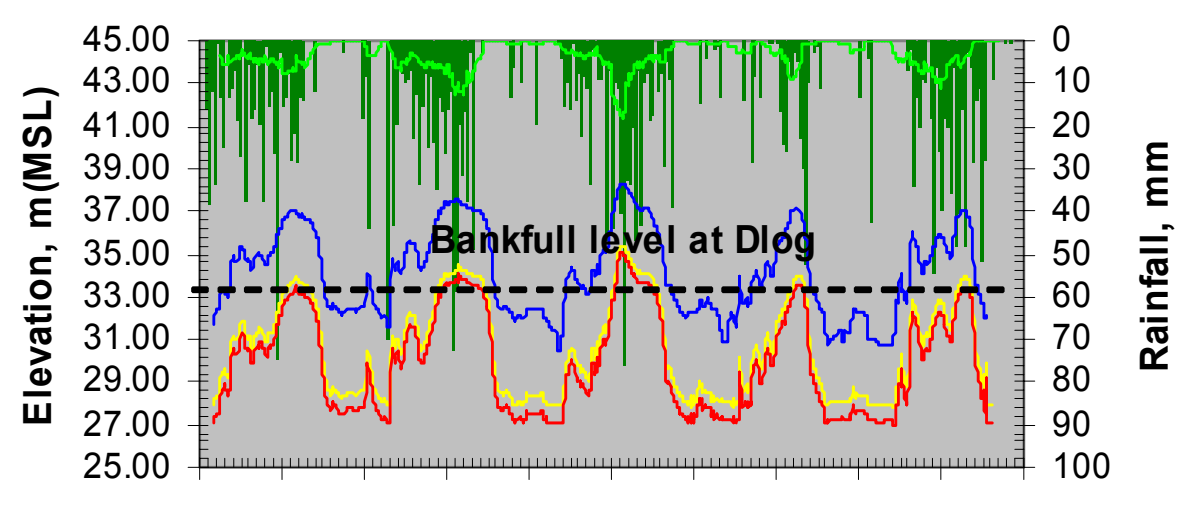

Phreatic surface

fluctuations within

the tropical

floodplain

S. Chuenchooklin et al.

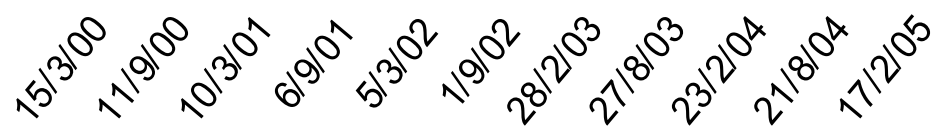

Fig. 9. Daily rainfall and water surface level in the Yom River (RWL) at observation stations during 2000-2004.

Title Page

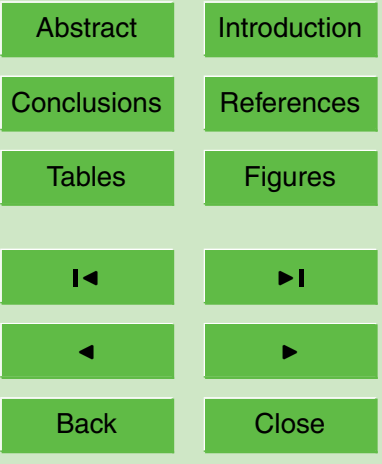

Full Screen / Esc

Print Version

Interactive Discussion 


\section{HESSD}

2, 731-760, 2005

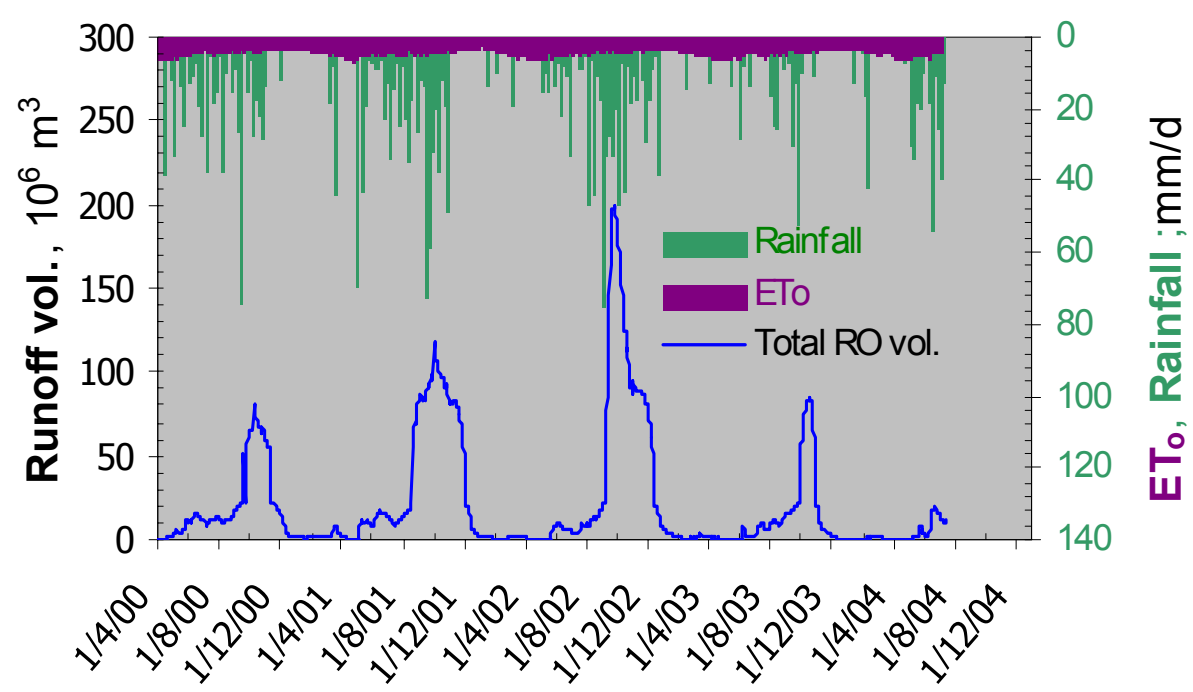

Fig. 10. Daily $P, E T$, runoff vol. $(\mathrm{RO})$ on floodplain and river channel via study area during 2000-2003.
Phreatic surface

fluctuations within

the tropical

floodplain

S. Chuenchooklin et al.

Title Page

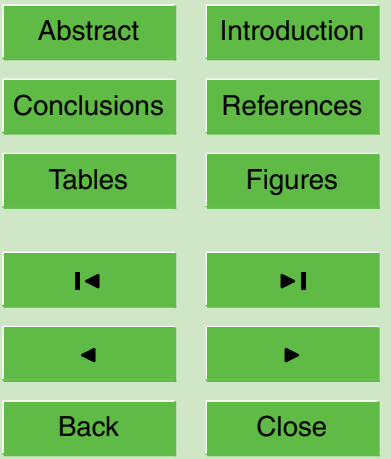

Full Screen / Esc

Print Version

Interactive Discussion 


\section{HESSD}

2, 731-760, 2005

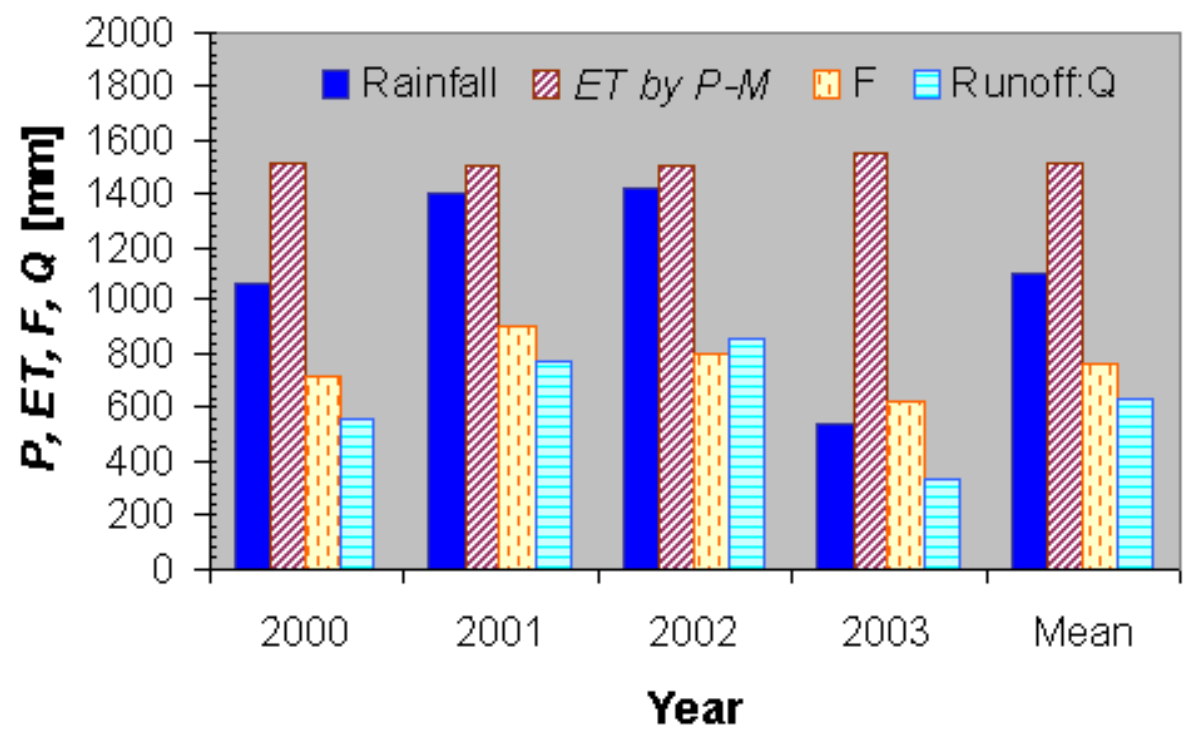

Fig. 11. Annual $P, E T, F, Q_{i n}[\mathrm{~mm}]$ at the upstream catchments to the inner zone during 2000-2003.
Phreatic surface

fluctuations within

the tropical

floodplain

S. Chuenchooklin et al.

Title Page

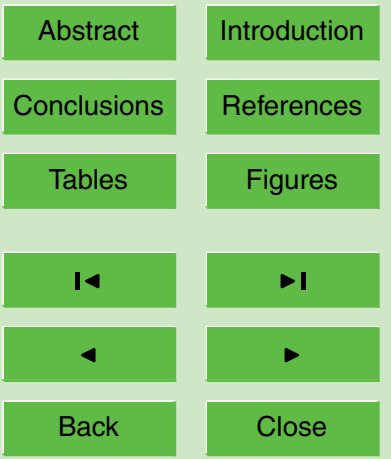

Full Screen / Esc

Print Version

Interactive Discussion 


\section{HESSD}

2, 731-760, 2005

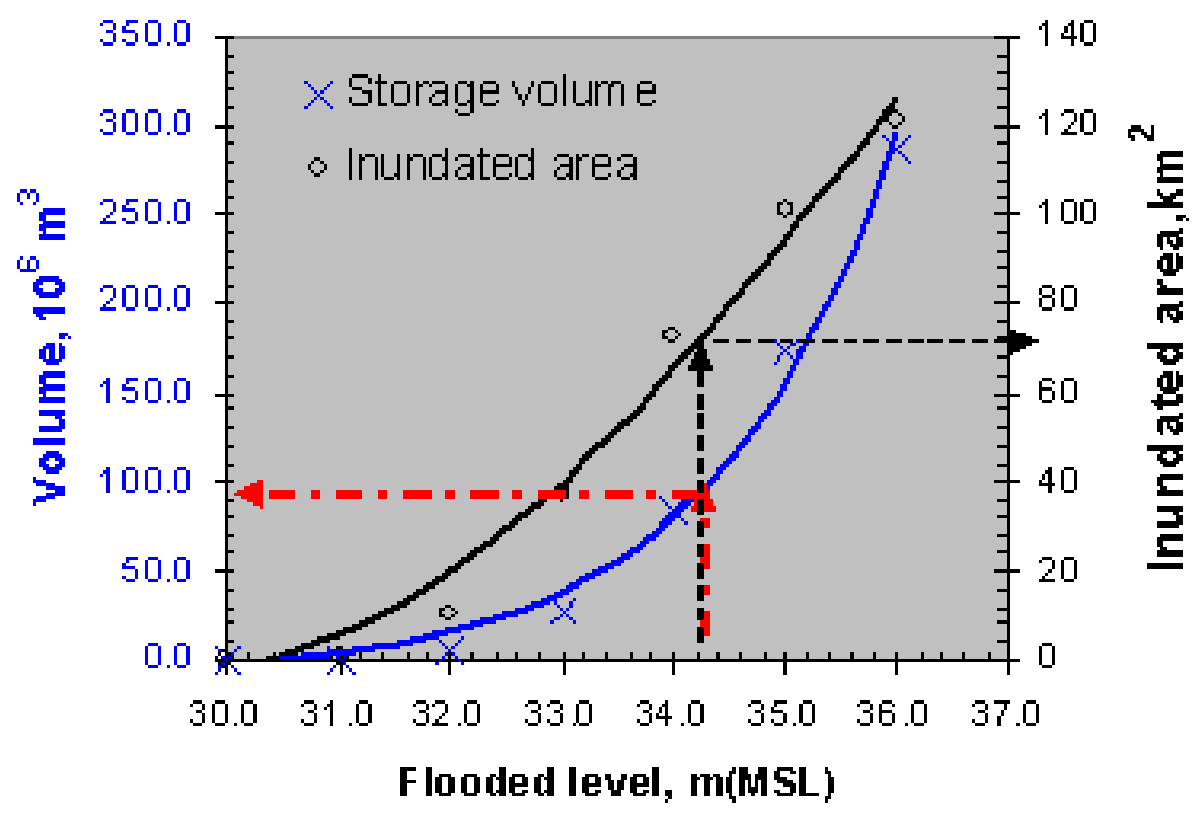

Fig. 12. Characteristic curves of flood pool level versus area, and flood pool levele versus storage volume in floodplain resulted by existing topography.
Phreatic surface fluctuations within the tropical floodplain

S. Chuenchooklin et al.

Title Page

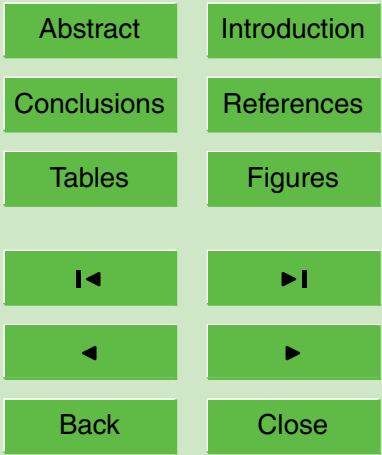

Full Screen / Esc

Print Version

Interactive Discussion 


\section{HESSD}

2, 731-760, 2005

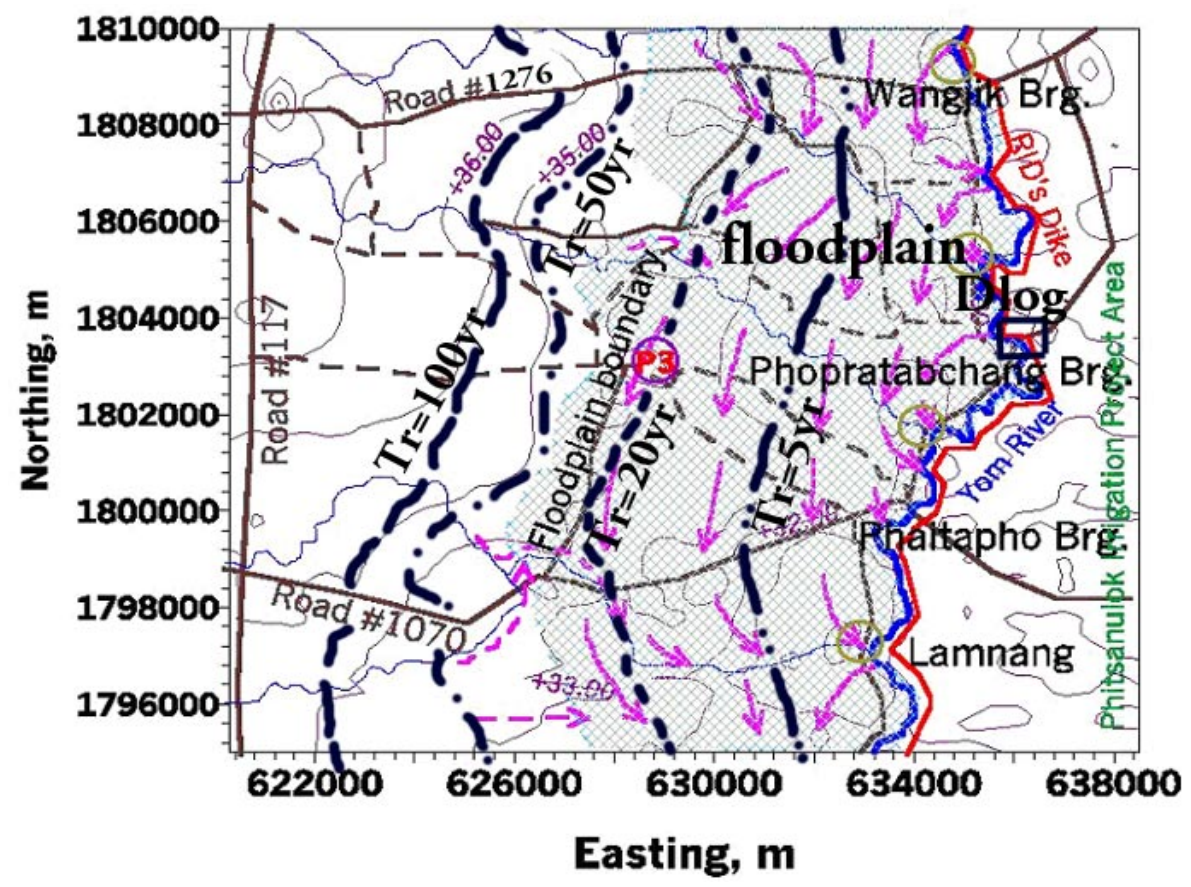

Phreatic surface fluctuations within the tropical floodplain

S. Chuenchooklin et al.

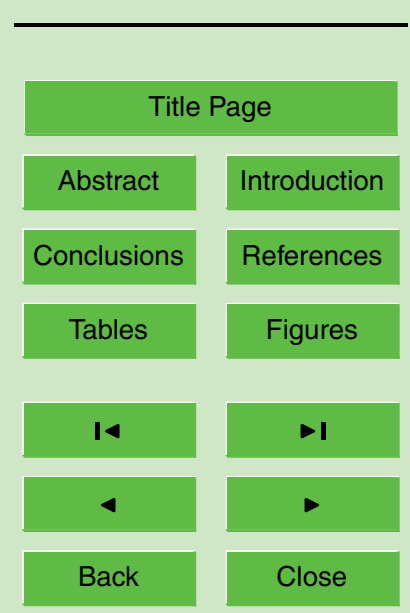

Fig. 13. Flood flow patterns in floodplain with the different frequencies (Tr) of $5 \mathrm{yr}, 20 \mathrm{yr}$, and

Full Screen / Esc $100 \mathrm{yr}$, respectively.

Print Version

Interactive Discussion 


\section{HESSD}

2, 731-760, 2005

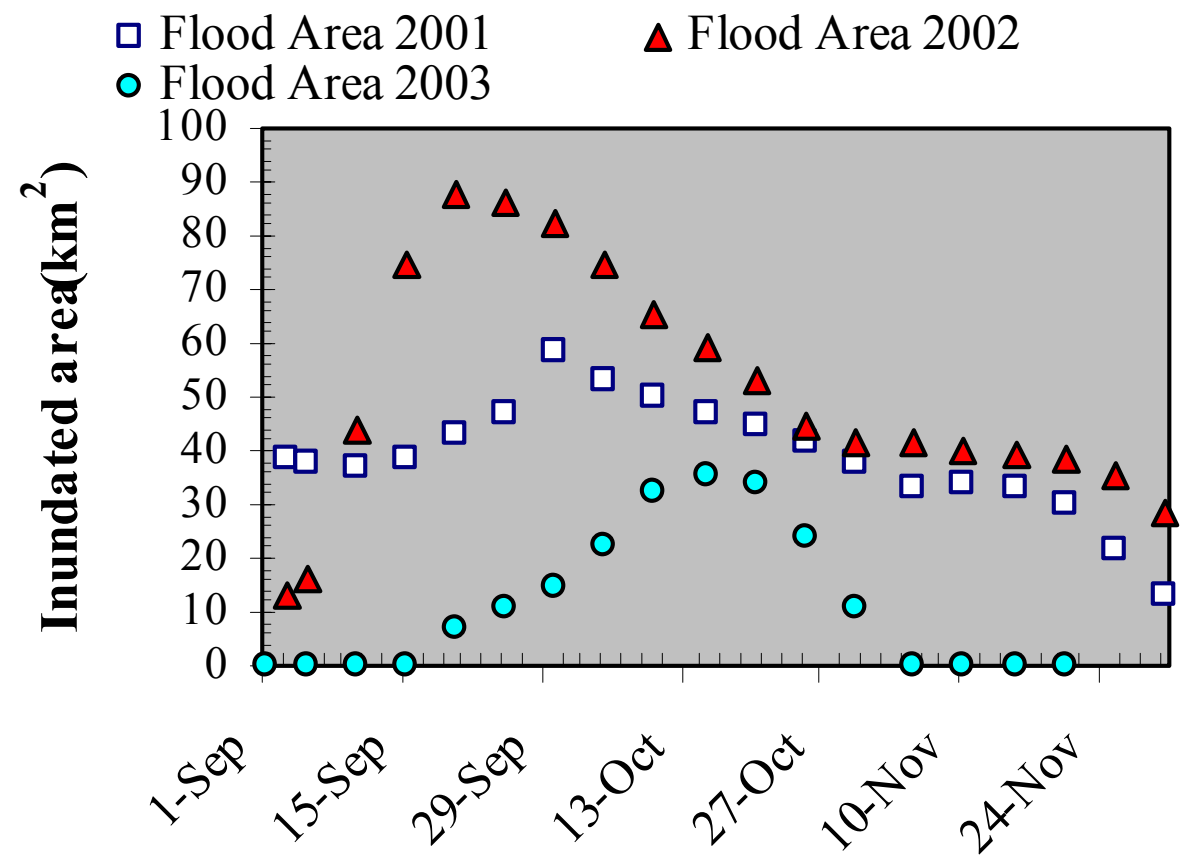

Phreatic surface fluctuations within the tropical floodplain

S. Chuenchooklin et al.

Title Page

Abstract

Conclusions

Tables

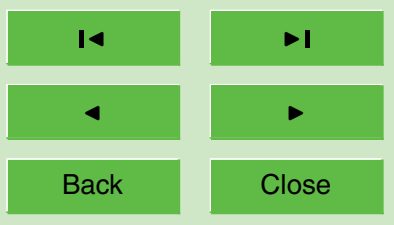

Full Screen / Esc

Fig. 14. Comparison of the inundated extents during 2001 to 2003. 


\section{HESSD}

2, 731-760, 2005

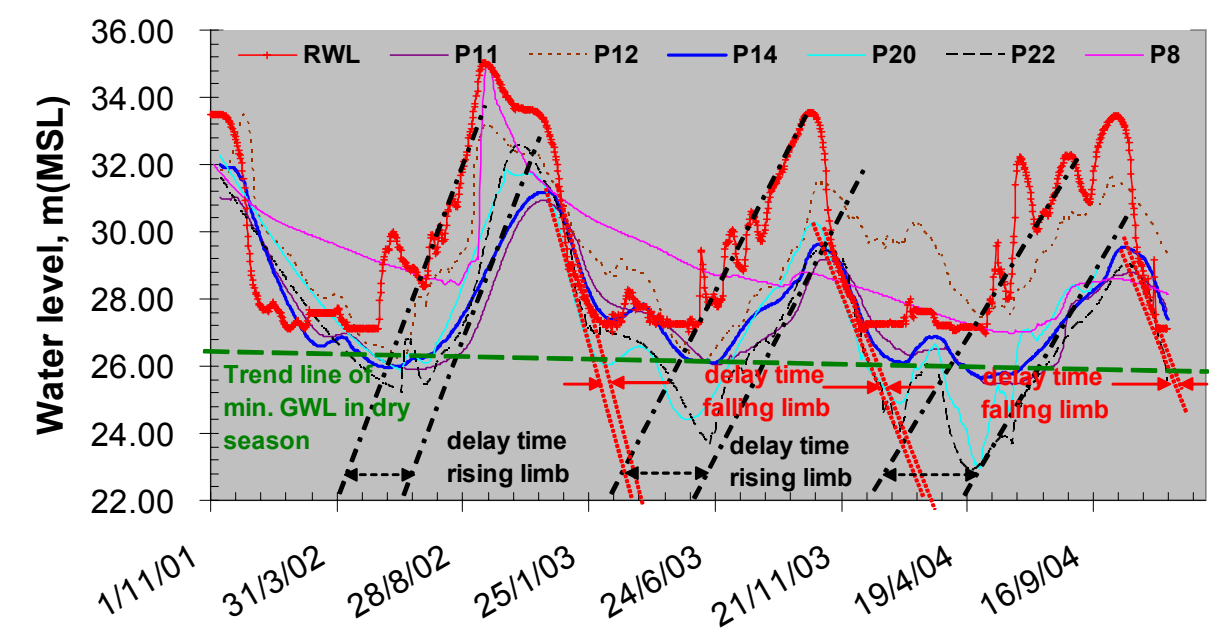

Fig. 15. Comparison between daily river stage (RWL) and phreatic surface (GWL) at some observation wells in floodplain with the downward slope of trend line during dry periods.

\section{Phreatic surface \\ fluctuations within \\ the tropical \\ floodplain}

S. Chuenchooklin et al.

\section{Title Page}

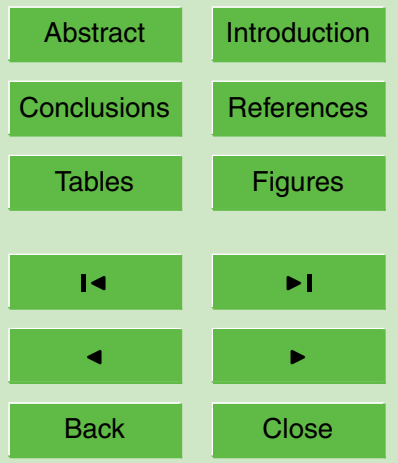

Full Screen / Esc

Print Version

Interactive Discussion 


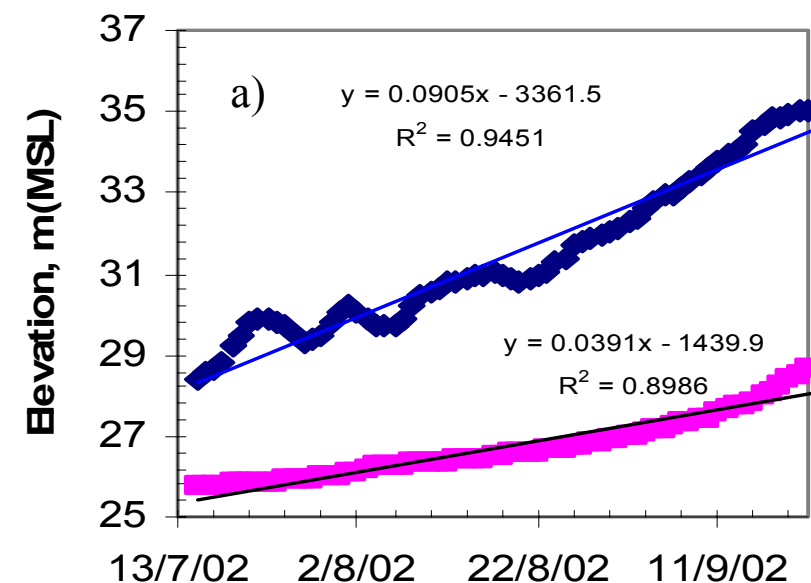

\section{HESSD}

$2,731-760,2005$

\begin{tabular}{|l|}
\hline - RWL \\
- GWL
\end{tabular}

(a)

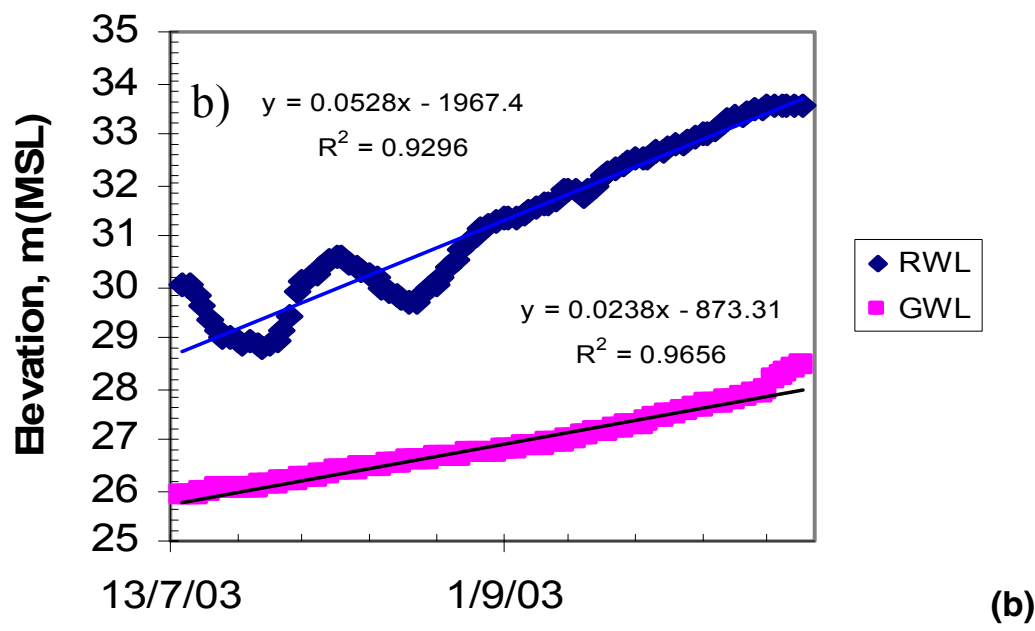

(b)
Title Page

Phreatic surface

fluctuations within

the tropical

floodplain

S. Chuenchooklin et al.

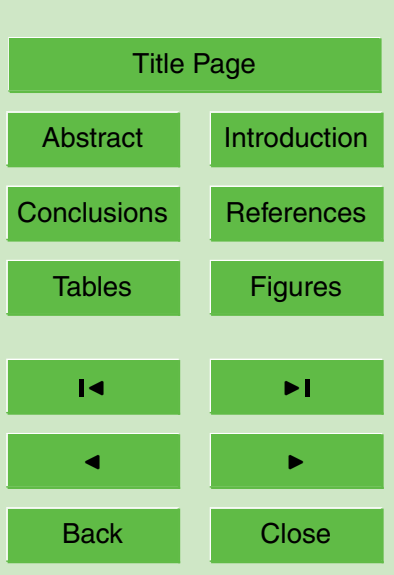

Full Screen / Esc

Print Version

Interactive Discussion

Fig. 16. Comparison between the trend lines of daily river stage (RWL) and phreatic surface (GWL) changed to the rising limbs of river hydrographs in the years: (a) 2002, and (b) 2003, respectively. 